\title{
PENGEMBANGAN BAHAN AJAR CETAK DENGAN MODEL DISCOVERY LEARNING UNTUK MATA PELAJARAN KOMPUTER DAN JARINGAN DASAR KELAS X JURUSAN TKJ SMK MUHAMMADIYAH 1 KEPANJEN
}

\author{
Ria Devita Meidy, \\ Syaad Patmanthara, \\ M. Zainal Arifin \\ Universitas Negeri Malang \\ E-mail: riainformatika2013f@gmail.com
}

\begin{abstract}
Abstrak
Metode pengembangan yang digunakan dalam penelitian dan pengembangan ini diadaptasi dari langkah-langkah penelitian dan pengembangan $(\mathrm{RnD})$ dengan melakukan sedikit modifikasi. Seluruh proses pengembangan terbagi dalam 10 langkah yakni : (1) masalah dan potensi, (2) pengumpulan data, (3) pengembangan produk, (4) validasi ahli materi dan ahli media, (5) revisi produk, (6) uji kelompok kecil, (7) revisi produk, (8) Uji coba kelompok besar, (9) revisi produk, (10) produksi Produk. Hasil penelitian dan pengembangan Buku Ajar Cetak Komputer dan Jaringan Dasar dengan model Discovery Learning yang telah dikembangkan dan divalidasi oleh beberapa ahli yaitu: (1) ahli materi diperoleh $94,1 \%$, (2) ahli media diperoleh $93,54 \%$, (3) uji coba kelompok kecil diperoleh $80,4 \%$, (4) uji coba kelompok besar diperoleh 91,96\%, dan ratarata keseluruhan diperoleh 90,79\%. Berdasarkan hasil validasi tersebut dapat dikatakan bahwa Bahan Ajar Cetak Komputer dan Jaringan Dasar Layak digunakan pada proses pembelajaran di SMK Muhammadiyah 1 Kepanjen, khususnya pada mata pelajaran Komputer dan Jaringan Dasar kelas X program keahlian TKJ.
\end{abstract}

Kata Kunci: Bahan Ajar Cetak, Discovery Learning, Komputer dan Jaringan Dasar

\begin{abstract}
The development method used in this research and development steps adapted from research and development $(\mathrm{RnD})$ that doing a little modification. The entire development process is divided into 10 steps: (1) problems and potential, (2) data collection, (3) product development, (4) expert validation material and media expert, product revision (5), (6) small group testing, product revision (7), (8) trial, a large group (9) revision of the product, (10) the production of the product. The results of the research and development of the print Textbook of the teaching computer and Basic Network Discovery Learning with a model that has been developed and validated by some experts, namely: (1) expert material retrieved $94.1 \%$, (2) media experts gained $93.54 \%$, (3) test group $80.4 \%$, obtained a small (4) large groups of trials retrieved $91.96 \%$, and overall average gained $90.79 \%$. Based on the results of the validation can be said that the Printed of learning materials of the computer and basic network is feasibility to be used in the learning process in SMK Muhammadiyah 1 Kepanjen, particularly on the subjects of computer and Basic network class $\mathrm{X}$ programs vocational skills on Computer Engineering and Networks (TKJ).
\end{abstract}

Keyword: Printed of teaching Materials Development, Discovery Learning, Printed of teaching Materials

\section{PENDAHULUAN}

Sejalan dengan tuntutan era global yang bertumpu pada kemampuan profesional, aktivitas pembelajaran di glembaga-lembaga pendidikan menengah tidak hanya difokuskan pada upaya mendapatkan pengetahuan secara teori sebanyakbanyak nya, tetapi juga harus memanfaatkan perkembangan teknologi guna meningkatkan kualitas pembelajaran. Peningkatan kualitas pembelajaran diharapkan dapat menciptakan kemampuan profesional di bidang tertentu yang sangat penting artinya bagi pelajar dan masa depannya. Para ahli pembelajaran umumnya sependapat bahwa kemampuan dasar profesi dalam batas-batas tertentu, dapat dibentuk dan dikembangkan melalui kegiatan belajar bidang studi dan disiplin ilmu yang diajarkan (Arikunto \& Yuliana, 2008). Kesuksesan individu dalam dunia kerja pada abad ke-21 tidak cukup hanya berpengetahuan luas saja, tetapi juga bagaimana menyimpan pengetahuan saat ini, mengaplikasikannya untuk memecahkan masalah baru, dan berfungsi sebagai anggota tim. Adab ke21 sebagai abad belajar menuntut perubahan paradigma belajar. Perubahan paradigma tersebut tercermin dalam perubahan pandangan terhadap belajar dan mengajar yang lebih menekankan pada 
dimensi sosial dan kostruktivisik(Trianto \& Pd, 2007). Penghargaan terhadap keseragaman (uniformity) dan kesesuaian (conformity) tidak adil bagi pebelajar saat ini. Pebelajar harus belajar untuk bekerja pada tim dari budaya dan latar belakang berbeda, belajar mandiri dan mengetahui bagaimana mengelola waktu, mengetahui bagaimana memecahkan masalah, bagaimana melakukan tugas ganda, dan bagaimana mengakses informasi. Dengan demikian, kegiatan pembelajaran bukan berpusat pada guru, tetapi berpusat pada pembelajar atau siswa. Pembelajaran yang berpusat pada pembelajar membutuhkan dukungan berbagai media dan sumber belajar.

Salah satu program kompetensi yang diharapkan dari program keahlian teknik komputer dan jaringn (TKJ) adalah software-hardware pada komputer, konsep jaringan, serta rancang bangun server. Berdasarkan hasil wawancara Kepala Sekolah dan Guru Mata pelajaran Komputer dan Jaringan Dasar merupakan pelajaran yang masih baru karena mata pelajaran ini muncul pada Kurikulum 2013 revisi tahun 2017, dimana mata pelajaran ini merupakan mata pelajaran yang dikembangkan dari mata pelajaran sebelumnya yaitu Jaringan Dasar, untuk kelas X sementara ini pembelajaran pada mata pelajaran tersebut masih mengacu pada buku Jaringan Dasar, yang materinya kurang spesifik serta isi dari buku tersebut sulit di pahami oleh siswa. pengetahuan guru mata pelajaran dan mengambil bahan-bahan dari internet sesuai KD. Salah satu aspek untuk mencapai penguasaan terhadap materi diperlukan suatu media. Terdapat beberapa masalah dalam proses pembelajaran mata pelajaran tersebut, yaitu hingga saat ini pembelajaran Komputer dan Jaringan Dasar masih dilakukan metode ceramah dan presentasi sehingga penyampaian materi tersebut kurang interaktif dan komunikatif yang mengakibatkan siswa mengalami kesuliatan dalam memahami materi. Beberapa hal tersebut berdampak pada minat siswa dalam mengikuti mata pelajaran Komputer dan Jaringan Dasar.

Rendahnya minat belajar siswa disebabkan oleh banyak faktor terutama adalah faktor media pembelajaran yang saat ini digunakan pada SMK Muhammadiyah 1 Kepanjen, karena terletak pada daerah yang bukan di perkotaan untuk itu keterbatasan bahan ajar online menjadi salah satu masalah bagi pembelajaran di SMK Muhammadiyah 1 Kepanjen. Sehingga siswa hanya belajar bersumber dari materi yang diberikan oleh guru. Menurut Observasi lapangan, LCD proyektor juga belum ada disemua kelas misalnya kelas teori, LCD proyektor hanya ada di Lab praktikum saja. Dengan demikian perlu dikembangkan bahan ajar yang mampu mendukung pembelajaran siswa di lingkungan yang telah digambarkan diatas dan yang sesuai dengan kebutuhan siswa. Maka untuk itu perlu dikembangkannya bahan ajar yang mendukung siswa untuk belajar dan kemudahan mengakses materi, bahan ajar yang sesuai dengan masalah tersebut adalah Bahan ajar Cetak karena bahan ajar cetak dapat diakses tanpa menggunakan internet dan setiap siswa bisa memiliki bahan ajar tersebut sehingga kapanpun siswa memerlukan materi untuk belajar siswa tidak akan kesulitan untuk mengakses materi. Dalam penelitian yang berjudul "Penembangan Bahan Ajar Cetak dengan Menggunakan Model Discovery Learning untuk Meningkatkan Minat Belajar Siswa pada Mata Pelajaran Komputer dan Jaringan dasar Kelas X Program Keahlian TKJ di SMK Muhammadiyah 1 Kepanjen" diharapkan mampu memunculkan minat belajar siswa pada mata pelajaran tersebut. Pengembangan tersebut di angkat dari beberapa referensi buku cetak sebelumnya dan beberapa jurnal seperti : Buku Cetak Jaringan Dasar Kelas X yang diterbitkan oleh Direktorat Pembinaan Pendidikan KEJURUAN tahun 2014, Jurnal-jurnal tentang materi yang mengacu pada KI dan KD Kurikulum 2013 Revisi tahun 2017(Oemar, 1993).

Tujuan dari pengembangan Bahan Ajar Cetak ini adalah : (1) menyediakan bahan ajar yang sesuai dengan tuntutan kurikulum dengan mempertimbangkan kebutuhan peserta didik, yakni bahangajar yang sesuai dengan karakteristik dan setting atau lingkungan sosial peserta didik, (2) mengembangkan bahan ajar yang efektifitas untuk SMK sehingga mampu meningkatkan minat belajar dan minat baca siswa terutama untuk mata pelajaran Komputer dan Jaringan Dasar kelas X di SMK Muhammadiyah 1 Kepanjen, dan (3) mengetahui kelayakansbahan ajar yang dikembangkan untuk mata pelajaran Komputer dan Jaringan Dasar kelas X di SMK Muhammadiyah 1 Kepanjen.

(Prastowo, 2012)Bahan ajar pada dasarnya merupakan segala bahan (baik informasi, alat, maupun teks) yang disusun secara sistematis, yang menampilkan sosok utuh dari kompetensi yang akan dikuasai siswa dan digunakan dalam dalam proses pembelajaran dengan tujuan perencanaan dan penelaahan implementasi pembelajaran.

Berdasarkan website (Depdiknas \& No, 2003)"bahan ajar merupakan seperangkat materi/substansi pembelajaran (teaching material) yang disusun secara sistematis, menampilkan sosok utuh dari kompetensi yang akan dikuasai siswa dalam kegiatan pembelajaran". Selanjutnya, (Depdiknas \& No, 2003)mendefinisikan "bahan ajar atau materi pembelajaran (instuctional materials) secara garis besar terdiri dari pengetahuan, keterampilan, dan sikap yang harus dipelajari siswa dalam rangka mencapai standar kompetensi yang telah di tentukan”. 
Pengembangan Bahan Ajar Cetak Dengan Model Discovery Learning Untuk Mata Pelajaran Komputer Dan Jaringan Dasar Kelas X Jurusan Tkj Smk Muhammadiyah 1 Kepanjen

Ria Devita Meidy, Syaad Patmanthara, M. Zainal Arifin

\section{METODE}

(Setyosari, 2016)Penelitian ini merupakan penelitian pengembangan pendidikan (educational research and development) yang mengembangkan bahan ajar pada mata pelajaran Komputer dan Jaringan Dasar. Penelitian dan pengembangan adalah suatu proses atau langkah-langkah untuk mengembangkan suatu produk baru atau menyempurnakan produk yang telah ada, yang dapat di pertanggung jawabkan (Jonathan, 2006)Penelitian pengembangan pendidikan meliputi proses penelitian, pengembangan dan validasi produk. Melalui penelitian pengembangan, peneliti berusaha untuk mengembangkan suatu produk yang efektif untuk digunakan dalam pembelajaran. Produk yang akan dihasilkan dalam penelitian ini beruba Bahan Ajar "Buku Cetak" dengan tampilan yang lebih menarik dan dari segi isi lebih mengacu pada inti materi, hal ini bertujuan untuk memotivasi belajar terhadap peserta didik supaya lebih tertarik untuk membaca dan memahami isi buku.

(Sugiyono, 2008)Metode pengembangan bahan ajar yang akan digunakan ialah metode penelitian dan pengembangan (research and development/R\&D), dengan melakukan sedikit modifikasi langkah pada metode ini sesuai dengan kondisi lapangan dan waktu yang dibutuhkan dalam proses pengembangan, namun tidak mengurangi jumlah langkah-langkah pengembangan tersebut. Modifikasi ini bertujuan untuk efektifitas proses pengembangan buku ajar agar dapat berjalan deengan optimal.

Langkah metode penelitian $R \& D$ (Sugiyono, 2009) yang dimodifikasi yaitu pada bagian langkah uji keefektifan tidak dilakukan karena pada tujuan awal pengembangan buku ajar ini adalah untuk mrnguji kelayakan buku ajar. Pada langkah terakhir yaitu produksi massal, tidak dilaksanakan.

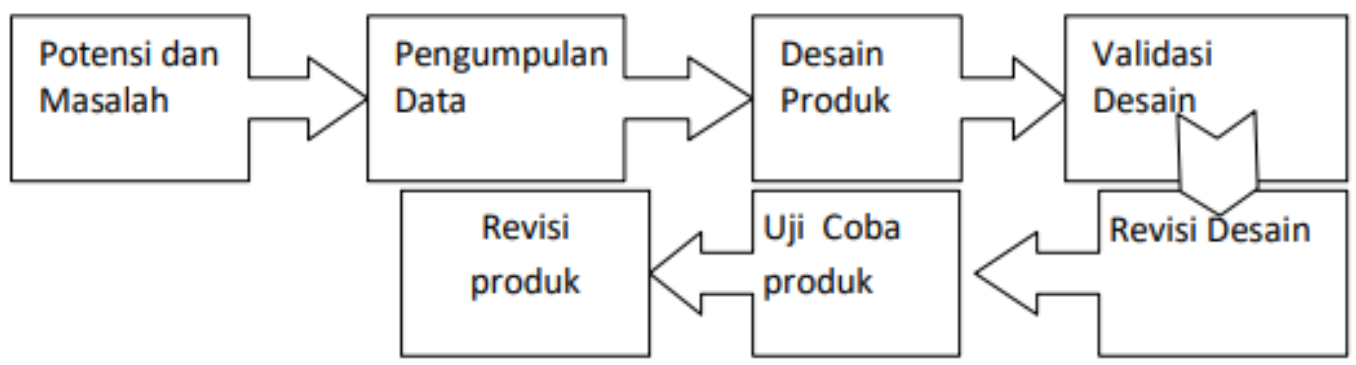

Bagan 1. Alur Pengembangan dalam Penelitian

Jenis data yang diperoleh dalam pengembangan bahan ajar akan berupa data kuantitatif dan kualitatif. Data kualitatif berupa nilai-nilai yang didapatkan dari angket, sehingga dapat diketahui layak atau tidak layaknya bahan ajar yang dikembangkan berupa buku cetak. Ditambah dengan data kuantitatif berupa tanggapan atau komentar, kritik dan saran dari subyek coba. Dengan data-data tersebut, dapat diketahui bahwa bahan ajar tersebut perlu dilakukian revisi atau tidak. Proses pengumpulan data dilakukan dengan menggunakan angket, untuk lebih jelasnya lihatlah pada tabel 1

Tabel 1 Jenis Data dan instrumen pengumpulan data.

\begin{tabular}{ccccc}
\hline & $\begin{array}{c}\text { Subyek Uji } \\
\text { Coba/Valida }\end{array}$ & \multicolumn{2}{c}{ Jenis data } & $\begin{array}{c}\text { Instumen } \\
\text { pengumpul } \\
\text { No }\end{array}$ \\
si & Kualitat & $\begin{array}{c}\text { Kuantitat } \\
\text { if }\end{array}$ & if \\
\hline 1. & Ahli Materi & $\sqrt{ }$ & $\sqrt{ }$ & Angket \\
2. & Ahli Media & $\sqrt{ }$ & $\sqrt{ }$ & Angket \\
3. & Responden & $\sqrt{ }$ & $\sqrt{ }$ & Angket \\
\hline
\end{tabular}

Data yang telah terkumpul akan dianalisis untuk mengetahui kualitas produk pengembangan yang dihasilkan. Data-data tentang produk yang dikembangkan, yaitu aspek materi dalam bahan ajar dan tampilan produk bahan ajar yang akan digunakan untuk merevisi produk. pengumpulan data dilakukan dengan cara memberi angket kepada ahli media, ahli materi, guru matapelajaran, dan siswa.

Analisis data yang digunakan dalam penelitian ini adalah analisis secara deskriptif dengan langkah-langkah sebagai berikut :

1. Pengumpulan data kasar diperoleh dari validasi ahli materi, ahli media, guru matapelajaran dan siswa.

2. Tabulasi semua data yang diperoleh dari penilaian menggunakan skala likert. Skala likert dikembangkan oleh Rensis Likert yang sering digunakan untuk mengukur sikap, pendapat, persepsi, dari responden terhadap suatu objek (Usman \& Profesional, 2009) Pada tahap ini penilaian data dalam bentuk kualitatif menjadi kuantitatif. 
Tabel 2 Skala Likert

\begin{tabular}{ll}
\hline Skor & Nilai \\
\hline 1 & Sangat Kurang \\
2 & Kurang \\
3 & Cukup \\
4 & Baik \\
5 & Sangat Baik \\
\hline
\end{tabular}

\section{Mengolah Data Per Butir Pertanyaan}

Rumus dibawah ini digunakan untuk menghitung data per butir pertanyaan dari angket insrtumen pengumpulan data. Dengan subjek coba yaitu siswa kelas X Jurusan Teknik komputer dan Jaringan SMK Muhammadiyah 1 Kepanjen.

$\mathrm{V}_{\text {butir }}=\frac{T \& g}{T s h} \times 100$

Keterangan

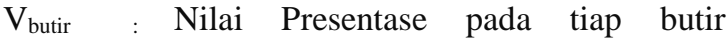
pertanyaan.

$\mathrm{T}_{\mathrm{se}} \quad$ : Skor empirik dari ahli atau subjek uji coba pada setiap butir pertanyaan

$\mathrm{T}_{\text {seh }} \quad$ : Skor maksimal yang dapat diberikan oleh ahli atau subjek uji coba pada setiap butir pertanyaan.

\section{Mengolah Data Per Aspek Kelayakan}

Data kelayakan yang merupakan data kualitatif perlu dijadikan data dalam bentuk data kuantitatif. Rumus dibawah ini digunakan untuk menghitung data kualitatif menjadi Kuantitatif.

$\mathrm{V}_{\text {aspek }}=\frac{\text { TSEasp }}{\text { THEasp }} \times 100$

Keterangan

$\mathrm{V}_{\text {aspek }}$ : Nilai Presentase pada tiap aspek kelayakan.

$\mathrm{TSE}_{\text {asp }}$ : Skor empirik dari ahli atau subjek uji coba pada setiap aspek kelayakan

$\mathrm{THE}_{\text {asp }} \quad$ : Skor maksimal yang dapat diberikan oleh ahli atau subjek uji coba pada setiap aspek kelayakan.

Guna mengambil keputusan untuk melakukan revisi pada buku ajar yang dikembangkan, digunakanlah kriteria kualifikasi penilaian yang diadaptasi dari Akbar (2013:41) seperti yang dijelaskan pada tabel 3. buku ajar dapat dikatakan layak jika mencapai kriteria minimal cukup valid $(70,01 \%-85,00 \%)$

Tabel 3 Kriteria Analisa Presentase

\begin{tabular}{cc}
\hline $\begin{array}{c}\text { Kriteria } \\
\text { kelayakan }\end{array}$ & Tingkat Validitas \\
\hline $85,01 \%-$ & Sangat valid atau \\
$100 \%$ & digunakan tanpa revisi \\
$70,01 \%-$ & Cukup valid dapat \\
$85,00 \%$ & digunakan dengan \\
& revisi kecil \\
$50,01 \%-$ & Kurang valid,
\end{tabular}

\begin{tabular}{cc}
\hline $\begin{array}{c}\text { Kriteria } \\
\text { kelayakan }\end{array}$ & Tingkat Validitas \\
\hline $70,00 \%$ & disarankan tidak \\
& dipergunakan karena \\
perlu revisi besar \\
$01,00 \%-$ & Tidak valid tidak boleh \\
$50,00 \%$ & digunakan \\
\hline Sumber: Akbar, 2013:41
\end{tabular}

HASIL

\section{Deskripsi Hasil Pengembangan Bahan Ajar}

Buku ajar berjudul "Komputer dan Jaringan Dasar" merupakan bahan ajar yang digunakan sebagai media pembelajaran pada proses pembelajaran Komputer dan Jaringan Dasar Jurusan Teknik Komputer dan Jaringan di SMK Muhammadiyah 1 Kepanjen, sehingga dapat memudahkan siswa dalam memahami materi Komputer dan Jaringan Dasar. Materi yang dibahas dalam buku ajar ini adalag materi untuk semester Genap (dua) pada mata pelajaran Komputer dan Jaringan Dasar.

Pengembangan buku ini terdapat 5 pokok bahasan yang telah disesuaikan dengan silabus yang digunakan SMK Muhammadiyah 1 Kepanjen. Pokok bahasan yang terdapat pada buku ini yaitu (1) Konsep Jaringan Komputer, (2) Internet Protocol (IP) pada jaringan komputer, (3) Sumberdaya berbagi pakai pada Jaringan Komputer, (4) Instalasi koneksi pada Workstation, dan (5) LAN (Local Area Network).

Sebelum memasuki setiap pokok bahasan, terdapat peta konsep materi pembelajaran yang akan dipelajari siswa selama semester genap yang berguna untuk memberikan gambaran awal mengenai materi yang akan mereka pelajari.

Pada pengembangan buku ini terdiri dari Cover Kata Pengantar, daftar isi, Peta Konsep semester genap, Kompetensi Inti, Kompetensi Dasar, Indikator, Tujuan Pembelajaran, Poko bahasan, Kesimpulan, Soal dan Daftar Rujukan. Setiap pokok bahasan terdiri dari Peta Konsep semester genap, Kompetensi Inti, Kompetensi Dasar, Indikator, Tujuan Pembelajaran, Poko bahasan, Kesimpulan, Soal.

\section{Penyajian Data Uji Coba dan Analisis Data}

Penyajian data diperoleh dari hasil pengolahan perhitungan presentase kelayakan bahan ajar yang dilakukan sesuai dengan rumus yang digunakan untuk pengolahan data. Data uji coba tersebut diperoleh dari hasil validasi oleh para ahli, hasil uji coba kelompok kecil dan hasil uji coba pada kelompok besar. Validasi yang dilakukan oleh para ahli dibagi menjadi dua bagian yaitu validasi oleh ahli materi dan ahli media. Sedangkan hasil uji 
Pengembangan Bahan Ajar Cetak Dengan Model Discovery Learning Untuk Mata Pelajaran Komputer Dan Jaringan Dasar Kelas X Jurusan Tkj Smk Muhammadiyah 1 Kepanjen

Ria Devita Meidy, Syaad Patmanthara, M. Zainal Arifin

coba diperoleh dari penyebaran angket kepada siswa.

Data hasil validasi ahli materi diperoleh dari Bapak M. Zainal Arifin, S.Si.,M.Kom. yang merupakan dosen Jurusan Teknik Elektro. Berdasarkan data hasil validasi yang dilakukan oleh Bapak M. Zainal Arifin, S.Si.,M.Kom. analisa data yang dihasilkan pada seluruh aspek penilaian terhadap buku ajar, ahli materi berpendapat bahwa buku ajar sudah sangat baik. Berikut merupakan data hasil validasi oleh Bapak M. Zainal Arifin, S.Si.,M.Kom. yang ditunjukkan pada tabel 4.

Tabel 4 Hasil Validasi Ahli Materi

\begin{tabular}{clccc}
\hline No & $\begin{array}{c}\text { Aspek } \\
\text { Yang } \\
\text { dinilai }\end{array}$ & Skor & $\begin{array}{c}\text { Jawaban } \\
\text { Ideal }\end{array}$ & Presentase \\
\hline 1. & $\begin{array}{l}\text { Kelayakan } \\
\text { isi }\end{array}$ & 76 & 84 & $90,47 \%$ \\
2. & $\begin{array}{l}\text { Kelayakan } \\
\text { Penyajian } \\
\text { Kelayakan } \\
\text { Bahasa }\end{array}$ & 45 & 48 & $93,75 \%$ \\
\hline & Jumlah & 171 & 184 & $96,15 \%$ \\
\hline
\end{tabular}

Berdasarkan analisis tersebut, hasil yang diperoleh dari ahli materi mengacu pada tabel 2 tentang kriteria validitas analisis presentase. Hasil uji coba ahli materi diperoleh hasil rata-rata 95,10\% sehingga dapat dikatakan bahwa bahan ajar ini sangat valid dan dapat digunakan tanpa perlu revisi. Misalnya dari hasil validasi ahli materi untuk indikator,(a) Kesesuaian materi dengan Standar Kompetensi dan Kompetensi dasar, (b) Keakuratan Materi diperoleh skor 4 , sehingga diperoleh hasil $100 \%$ dan dinyatakan valid. Namun menyempurnakan buku ajar Komputer dan Jaringan Dasar untuk SMK Muhammadiyah 1 Kepanjen kelas $\mathrm{X}$ program keahlian Teknik Komputer dan Jaringan sebelum digunakan untuk uji coba perlu dilakukan revisi. Revisi buku ajar tersebut dapat dilakukan berdasarkan data kualitatif hasil validasi dari ahli materi pada menunjukkan catataan, tanggapan atau saran yang diberikan oleh validator ahli materi terhadap buku ajar.

Tabel 5 Hasil validasi oleh ahli materi dari SMK Muhammadiyah 1 Kepanjen

\begin{tabular}{|c|c|c|c|c|}
\hline No & $\begin{array}{c}\text { Aspek } \\
\text { Yang } \\
\text { dinilai }\end{array}$ & Skor & $\begin{array}{c}\text { Jawaban } \\
\text { Ideal }\end{array}$ & Presentase \\
\hline 1. & $\begin{array}{l}\text { Kelayakan } \\
\text { isi }\end{array}$ & 79 & 84 & $94,04 \%$ \\
\hline 2. & $\begin{array}{l}\text { Kelayakan } \\
\text { Penyajian }\end{array}$ & 46 & 48 & $95,83 \%$ \\
\hline 3. & $\begin{array}{l}\text { Kelayakan } \\
\text { Bahasa }\end{array}$ & 50 & 52 & $96,15 \%$ \\
\hline \multicolumn{2}{|c|}{ JUMLAH } & 175 & 184 & $95,10 \%$ \\
\hline
\end{tabular}

Hasil validasi diperoleh dari ahli materi yang mengacu pada tabel 3 tentang kriteria validitas analisis presentase. Hasil rata-rata yang diperoleh dari ahli materi secara keseluruhan menyatakan bahwa pengembangan buku ajar Komputer dan Jaringan dasar untuk kelas $\mathrm{X}$ jurusan Teknik Komputer dan Jaringan di SMK Muhammadiyah 1 Kepanjen sangat baik. Dari hasil rata-rata ahli materi diperoleh hasil rata-rata $92,93 \%$ sehingga dapat dikatakan bahwa buku ajar ini valid dan dapat digunakan tanpa revisi.

Data hasil validasi ahli media diperoleh dari Bapak M. Zainal Arifin, S.Si.,M.Kom. yang merupakan dosen Jurusan Teknik Elektro. Berdasarkan data hasil validasi yang dilakukan oleh Bapak M. Zainal Arifin, S.Si.,M.Kom. analisa data yang dihasilkan pada seluruh aspek penilaian terhadap buku ajar, ahli media berpendapat bahwa buku ajar sudah sangat baik. Berikut merupakan data hasil validasi oleh Bapak M. Zainal Arifin, S.Si.,M.Kom. yang ditunjukkan pada tabel 6

Tabel 6 Hasil validasi Ahli Media

\begin{tabular}{|c|c|c|c|c|}
\hline No & $\begin{array}{c}\text { Aspek } \\
\text { Yang } \\
\text { dinilai } \\
\end{array}$ & Skor & $\begin{array}{c}\text { Jawaban } \\
\text { Ideal }\end{array}$ & Presentase \\
\hline 1. & $\begin{array}{l}\text { Ukuran } \\
\text { Buku } \\
\text { Desain }\end{array}$ & 8 & 8 & $100 \%$ \\
\hline 2. & $\begin{array}{l}\text { Sampul } \\
\text { Buku } \\
\text { Desain }\end{array}$ & 35 & 36 & $97,22 \%$ \\
\hline 3. & $\begin{array}{l}\text { Isi } \\
\text { Buku }\end{array}$ & 73 & 80 & $91,25 \%$ \\
\hline \multicolumn{2}{|c|}{ Jumlah } & 116 & 124 & $93,54 \%$ \\
\hline
\end{tabular}

Berdasarkan analisis tersebut, hasil yang diperoleh dari ahli media mengacu pada tabel 2 tentang kriteria validitas analisis presentase. Hasil rata-rata yang diperoleh dari ahli media secara keseluruhan menyatakan bahwa buku ajar Komputer dan Jaringan dasar untuk Kelas X program keahlian Teknik Komputer dan Jaringan di 
DOI: http://dx.doi.org/10.26740/jp.v3n2.p126-133

SMK Muhammadiyah 1 Kepanjen sangat Valid dan dapat dipergunakan tanpa Revisi.

Hasil uji coba kelompok kecil dilakukan terhadap buku ajar Komputer dan Jaringan dasar kelas X jurusan Teknik Komputer dan jaringan di SMK Muhammadiyah 1 Kepanjen diperoleh dari pengisian angket. Uji coba dilakukan pada 10 siswa kela X jurusan Teknik komputer dan jaringan di SMK Muhammadiyah 1 Kepanjen yang menempuh mata pelajaran Komputer dan jaringan dasar dipilih secara acak. Data hasil uji coba kelompok kecil yang diperoleh ditunjukkan pada tabel 7 sebagai berikut.

Tabel 7 Hasil uji coba kelompok kecil

\begin{tabular}{c|l|c}
\hline No & \multicolumn{1}{|c|}{ Data yang diperoleh } & Skor \\
\hline 1. & $\begin{array}{l}\text { Jumlah keseluruhan jawaban } \\
\text { responden }(\Sigma \mathrm{X})\end{array}$ & 804 \\
\hline 2. & $\begin{array}{l}\text { Jumlah keseluruhan skor ideal } \\
\left(\Sigma \mathrm{X}_{\mathrm{i}}\right)\end{array}$ & 1000 \\
\hline
\end{tabular}

Berdasarkan data uji coba kelompok kecil pada 10 siswa kelas $\mathrm{X}$ jurusan teknik Komputer dan Jaringan di SMK Muhammadiyah 1 Kepanjen tersebut, maka dilakukan perhitungan untuk keseluruhan item / aspek sebagai berikut.

$\mathrm{V}=\frac{T s e}{T \sin } \times 100 \%$

$\mathrm{V}=\frac{\mathrm{g04}}{1000} \times 100 \%=80,04 \%$

Berdasarkan hasil analisa yang dipeoleh dari uji coba buku ajar melalui kelompok kecil dan mengacu pada tabel 2 mengenai kriteria validitas analisis presentase, hasil rata-rata yang diperoleh dari responden secara keseluruhan menyatakan bahwa buku ajar Komputer dan Jaringan dasar untuk kelas $\mathrm{X}$ jurusan Teknik Komputer dan Jaringan SMK Muhammadiyah 1 Kepanjen cukup baik. Hasil uji coba kelompok kecil yang dilakukan oleh siswa diperoleh hasil 80,04, sehingga dapat dikatakan bahwa buku ajar ini layak tetapi masih perlu sedikit revisi.

Data hasil uji coba kelompok besar yang dilakukan pada siswa kelas $\mathrm{X}$ jurusan Komputer dan Jaringan Dasar di SMK Muhammadiyah 1 Kepanjen sebanyak 28 Siswa. Data hasil Uji Coba kelompok besar terhadap buku ajar Komputer dan Jaringan dasar untuk kelas $\mathrm{X}$ jurusan Teknik Komputer dan jaringan di SMK Muhammadiyah 1 Kepanjen ditunjukkan pada tabel 8.
Tabel 8 hasil uji coba Kelompok Besar

\begin{tabular}{l|l|l}
\hline No & Data yang diperoleh & Skor \\
\hline 1. & $\begin{array}{l}\text { Jumlah keseluruhan jawaban } \\
\text { responden }(\Sigma \mathrm{X})\end{array}$ & 2575 \\
\hline 2. & $\begin{array}{l}\text { Jumlah keseluruhan skor ideal } \\
\left(\Sigma \mathrm{X}_{\mathrm{i}}\right)\end{array}$ & 2800 \\
\hline
\end{tabular}

Berdasarkan data hasil uji coba yang ditunjukkan pada tabel 4.9, maka dapat dilakukan perhitungan untuk keseluruhan item / aspek penilaian sebagai berikut.

$\mathrm{V}=\frac{T S E}{T H E} \times 100 \ldots \ldots \ldots \ldots \ldots \ldots \ldots \ldots \ldots \ldots \ldots \ldots \ldots$
$\mathrm{V}=\frac{2575}{2800} \times 100 \%=91,96 \%$

Berdasarkan hasil analisa yang dipeoleh dari uji coba buku ajar melalui kelompok besar dan mengacu pada tabel 3.5 mengenai kriteria validitas analisis presentase, hasil rata-rata yang diperoleh dari responden secara keseluruhan menyatakan bahwa buku ajar Komputer dan Jaringan dasar untuk kelas $\mathrm{X}$ jurusan Teknik Komputer dan Jaringan SMK Muhammadiyah 1 Kepanjen sangat baik, dengan hasil rata-rata 91,96\%, sehingga dapat dikatakan bahwa buku ajar ini layak dan dapat digunakan tanpa melalui revisi. Hal ini didukung oleh penelitian dan pengembangan yang dilakukan oleh Rizkia Pandu Setyawan dengan judul "Pengembangan Modul Pembelajaran Berbasis Mind Map Pada Mata Pelajaran Pemrograman Dasar di SMKN 1 Boyolangu" yang menyatakan modul tersebut layak.

Berdasarkan hasil uji coba kelompok besar tersebut didapatkan pula catatan atau saran dari subjek uji coba. Catatan dan saran tersebut menjadi gambaran bagaimana subjek uji coba dalam menggunakan dan merspon buku ajar Komputer dan Jaringan dasar untuk kelas X program keahlian Teknik Komputer dan Jaringan di SMK Muhammadiyah 1 Kepanjen yang dikembangkan, serta menjadi bahan pertimbangan untuk melakukan perbaikan pada buku ajar.

Setelah uji coba secara keseluruhan meliputi : (1) uji coba materi kepada ahli materi, (2) uji coba media kepada ahli media, (3) Uji coba kelompok kecil dan (4) Uji coba kelompok besar diperoleh data akhir sebagai berikut : 95,10\% untuk ahli materi dari Universitas Negeri Malang, 92,93\% untuk ahli materi dari SMK Muhammadiyah 1 Kepanjen, 93,54\% untuk ahli media, 80,4\% uji coba untuk kelompok kecil, dan 91,96\% untuk uji coba kelompok besar. Hasil rata-rata yang diperoleh dari keempat validator tersebut adalah $90,79 \%$. 


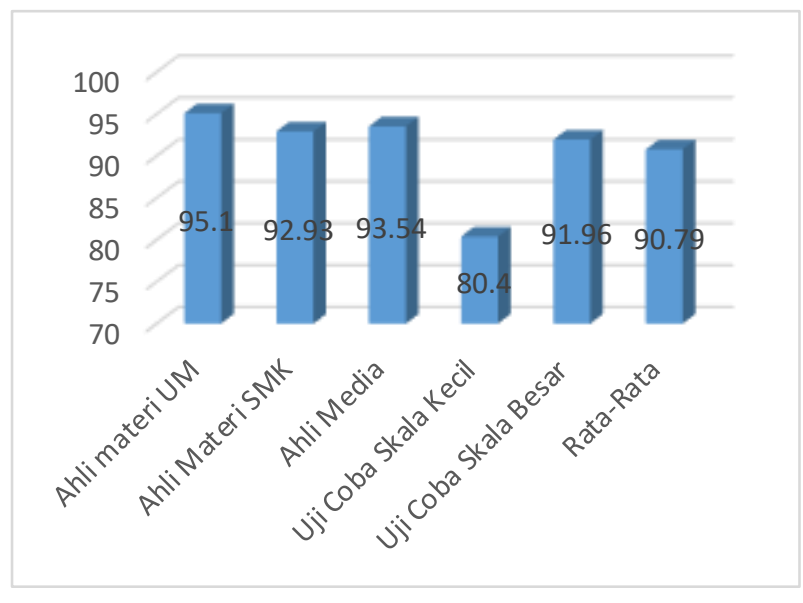

Gambar 1 Presentase Uji Coba Buku Ajar

Gambar 1 merupakan grafik presentasi uji coba buku ajar. Berdasarkan tabel 4.5 tentang kriteria validasi penilaian presentase, maka secara keseluruhan buku ajar "Komputer dan Jaringan dasar" untuk kelas X jurusan Teknik komputer dan Jaringan di SMK Muhammadiyah 1 Kepanjendinyatakan valid tanpa revisi.

\section{Pembahasan hasil pengembangan bahan ajar}

Produk yang dikembangkan berupa buku ajar cetak "Komputer dan Jaringan dasar" untuk kelas $\mathrm{X}$ Jurusan Teknik Komputer dan Jaringan untuk semester genap (dua) di SMK Muhammadiyah 1 Kepanjen. Setelah dilakukan uji kelayakan pengembangan buku ajar pada kedua ahli yaitu ahli materi dan media serta responden, diperoleh ratarata keseluruhan sebesar 90,79\%, sehingga buku ajar cetak “ Komputer dan Jaringan Dasar" untuk kelas X jurusan Teknik Komputer dan Jaringan di SMK Muhammadiyah 1 Kepanjen dinyatakan valid sebagai bahan ajar. Hal tersebut sesuai dengan uraian sebagai berikut :

1. Sampul yang digunakan dalam buku ajar disesuaikan dengan materi yaitu Komputer dan Jaringan Dasar dengan tujuan menarik minat baca peserta didik. Hal tersebut sesuai dengan pendapat Daryanto (2013:14) yang mengatakan bahwa "daya tarik dapat memberikan minat pada peserta didik untuk belajar dalam proses pembelajaran. Daya tarik dapat ditempatkan pada bagian sampul (cover) depan, dengan mengkombinasikan warna,gambar,bentuk dan ukuran huruf yang serasi...".

2. Materi dalam buku ajar tersusun secara sistematis sesuai dengan silabus yang digunakan di SMK Muhammadiyah 1 Kepanjen. Hal tersebut didukung oleh pendapat Pannen (2001) yang mengungkapkan bahwa bahan ajar adalah bahan-bahan atau materi yang disusun secara sistematis yang digunakan guru dan peserta didik dalam proses pembelajaran (Prastowo, 2011:17).

3. Buku ajar tersusun dari bagian-bagian berkesinambungan mulai dari judul bahan ajar, kompetensi Dasar, Peta Konsep, Tujuan Pembelajaran, Materi, Soal, Kesimpulan dan Glosarium. Hal tersebut seduai dengan pendapat Prastowo (2011:65) yang menyatakan bahwa bahan ajar terdiri dari beberapa unsur yaitu (a) judul, (b) kompetensi dasar, (c) materi pokok dan (d) informasi pendukung.

4. Tampilan bahan ajar jelas dan mudah dibaca. Tampilan yang terdapat dalam buku meliputi, (a) jenis huruf yang digunakan jelas dan mudah dibaca, (b) terdapat gambar ilustrasi untuk membantu peserta didik memahami materi. Hal tersebut sesuai dengan pendapat Prastowo (2011:174) yang menyatakan “... buku yang baik adalah buku yang memiliki tiga ciri yaitu menggunakan bahasa yang baik dan mudah dimengerti, penyajian menarik dan dilengkapi dengan gambar beserta keterangan-keterangan yang kompit...".

Hal tersebut didukung dengan hasil validasi yang dilakukan oleh ahli materi dengan hasil ratarata $94,01 \%$ sehingga dapat dikatakan bahwa bahan ajar ini valid dan dapat digunakan tanpa revisi. Sedangkan validasi dari ahli media dengan rata-rata 93,54\% sehingga bahan ajar ini dinyatakan valid dan dapat digunakan tanpa ada revisi. Untuk hasil uji coba pada kelompok kecil 80,4\% dan 91,96 uji coba kelompok besar. Sehingga buku ajar dinyatakan layak untuk digunakan sebagai bahan ajar pada mata pelajaran Komputer dan jaringan Dasar.

\section{PENUTUP}

Berdasarkan hasil pengembangan buku ajar "Komputer dan Jaringan Dasar" untuk kelas X Jurusan Teknik Komputer dan Jaringandi SMK Muhammadiyah 1 Kepanjen yang diawali dengan cara menganalisis potensi atau masalah yang dilakukan dengan cara pengamatan dan wawancara dengan peserta didik maupun guru mata pelajaran, kemudian dilanjutkan dengan melakukan perencanaan mengenai buku ajar yang memuat materi pembelajaran pada semester genap yaitu : 1) Konsep Jaringan Komputer, (2) Internet Protocol (IP) pada jaringan komputer, (3) Sumberdaya berbagi pakai pada Jaringan Komputer, (4) Instalasi koneksi pada Workstation, dan (5) LAN (Local Area Network). Setelah dilakukan perencanaan dilakukan pengembangan produk sesuai dengan yang telah direncanakan sebelumnya.

Setelah produk selesai dikembangkan, maka dilakukan validasi oleh ahli materi dan ahli media. Berdasarkan validasi dari ahli materi dan ahli 
media menyatakan buku ajar cetak telah valid, tetapi masih ada beberapa bagian yang perlu perbaikan. Berdasarkan data hasil pengembangan buku ajar cetak "Komputer dan Jaringan Dasar" untuk kelas $\mathrm{X}$ jurusan Teknik Komputer dan Jaringan di SMK Muhammadiyah 1 Kepanjen didapatkan beberapa saran untuk perbaikan pada buku ajar, yaitu (a) Perlu penambahan glosarium untuk mempermudah para siswa, (b) memberikan beberapa contoh pada materi, (c) menyesuaikan gambar dengan keterangannya, (d) mengganti font Calibri menjadi Times New Roman dan memperkecil jarak Spasi, dan (e) Merubah dari teks menjadi tabel pada Konpetensi dasar, Indikator dan Tujuan pembelajaran pada tiap bab.

Setelah dilakukan revisi ahli materi, ahli media maka dilakukan uji skala kecil untuk menguji tingkat kelayakan buku ajar cetak. Uji skala kecil pada buku ajar dinyatakan layak, namun masih ada saran dan tanggapan dari peserta didik yaitu (a) kalimat lebih diperjelas lagi, (b) diberi contoh soal dan penyelesaiannya, (c) ditambah glosarium pada buku, dan (d) diperjelas keterangan gambarnya. Langkah selanjutnya adalah melakukan revisi berdasarkan saran dan tanggapan dari peserta didik, yaitu memperjelas kalimat, menambahkan contoh soal, menambahkan glosarium dan keterangan gambar disesuaikan. Selanjutnya dilakukan uji coba skala besar, uji coba skala besar meyatakan buku ajar yang dikembangkan sudah layak.

Berikut merupakan tanggapan peserta didik pada uji skala besar yaitu : (a) buku ajar sudah baik, (b) sangat membantu dalam proses pembelajaran, (c) penyusunan kalimat diperbaiki dan (d) bukunya sudah cukup menarik. Berdasarkan tanggapan tersebut kemudian buku ajar disempurnakan lagi sesuai dengan tanggapan dari subjek uji coba.

Berdasarkan tujuan pengembangan bahan ajar berupa buku cetak "Komputer dan Jaringan Dasar" untuk kelas X Jurusan Teknik Komputer dan Jaringan di SMK Muhammadiyah 1 Kepanjen yang telah dikembangkan, maka dapat disimpulkan bahwa :

1. Perencanaan pengembangan buku ajar cetak "Komputer dan Jaringan Dasar" ini menggunakan metode pengembangan Sugiyono, dimana proses pengembangan terdiri dari (a) analisa potensi dan maslah, (b) perencanaan materi dalam buku, (c) pengembangan produk, (d) validasi ahli media dan ahli materi, (e) revisi produk, (f) uji coba kelompok keccil, (g) revisi produk, (h) uji coba kelompok besar, (i) revisi produk dan (j) Produksi Produk.

2. Penelitian dan pengembangan bahan ajar ini menghasilkan bahan ajar berupa buku ajar cetak untuk pelajaran Komputer dan Jaringan Dasar yang dapat membantu dan memudahkan peserta didik dalam memahami materi pada mata pelajaran Komputer dan Jaringan Dasar. Peserta didik dan guru dapat menjadikan buku ini sebagai acuan dari proses pembelajaran.

3. Setelah dilakukan uji coba secara keseluruhan meliputi : (1) uji coba materi kepada ahli materi, (2) uji coba media kepada ahli media, (3) uji coba kelompok kecil, dan (4) uji coba kelompok besar. Hasil rata-rata yang diperoleh dari keempat validator menyatakan bahwa buku ajar yang dikembangkan ini dinyatakan layak digunakan sebagai bahan ajar dalam proses pembelajaran tanpa harus dilakukan revisi.

\section{DAFTAR PUSTAKA}

Arikunto, S., \& Yuliana, L. (2008). Manajemen Pendidikan. Yogyakarta: Aditya Media.

Depdiknas, U.-U. R. I. N., \& No, R. I. (2003). Tahun 2003 Tentang Sistem Pendidikan Nasional. Jakarta: Dirjen Pendidikan Dasar Dan Menengah.

Jonathan, S. (2006). Metode Penelitian Kuantitatif dan Kualitatif. Jakarta: Graha Ilmu.

Oemar, H. (1993). Pengembangan Kurikulum Lembaga Pendidikan dan Pelatihan. Bandung: Trigondo Karya.

Prastowo, A. (2012). Metode Penelitian Kualitatif dalam Perspektif Rancangan Penelitian. Yogyakarta: Ar-Ruzz Media.

Setyosari, H. P. (2016). Metode Penelitian Pendidikan \& Pengembangan. Prenada Media.

Sugiyono. (2008). Metode Penelitian Pendidikan:(Pendekatan Kuantitatif, Kualitatif dan $R \& D)$. Jakarta: Alfabeta.

Sugiyono, D. R. P. (2009). Metode Penelitian Administrasi Dilengkapi dengan Metode $R \& D$. Revisi. Alfabeta.

Trianto, S. P., \& Pd, M. (2007). Model-Model Pembelajaran Inovatif Berorientasi Konstruktivistik. Jakarta: Prestasi Pustaka.

Usman, U., \& Profesional, M. G. (2009). Bandung: PT. Remaja Rosdakarya. 